The Evolution of the Hastings Coastline

Author(s): E. M. Ward

Source: The Geographical Journal, Vol. 56, No. 2 (Aug., 1920), pp. 107-120

Published by: geographicalj

Stable URL: http://www.jstor.org/stable/1781273

Accessed: 27-06-2016 17:34 UTC

Your use of the JSTOR archive indicates your acceptance of the Terms \& Conditions of Use, available at

http://about.jstor.org/terms

JSTOR is a not-for-profit service that helps scholars, researchers, and students discover, use, and build upon a wide range of content in a trusted digital archive. We use information technology and tools to increase productivity and facilitate new forms of scholarship. For more information about JSTOR, please contact support@jstor.org.

The Royal Geographical Society (with the Institute of British Geographers), Wiley are collaborating with JSTOR to digitize, preserve and extend access to The Geographical Journal 
Again, all other maps show villages as little circles and do not approach the pictorial design which the quarter-inch gives. The Aero Club de France also gives all sorts of chateaux and windmills. I suppose they are all very well when one is flying low, but after all one chateau is much like another, and there are so many of them that I think there is too much detail put in. The idea is to have the map free of unimportant detail, so that when you see some outstanding or unique feature through the clouds you can find it quickly on your map before clouds close over the gap and you are lost again.

The PREsident : Captain Lloyd has put forward his theory with great lucidity. He has made us understand what are the difficulties of the airman in the air, especially in times of war, and he has given what to us laymen seems a very excellent way of helping out the airman to find where he is. Evidently what we want to do is to hit off some means by which the main features, or at any rate what are the most conspicuous features, in a country can be identified by the airman flying many thousand feet above the Earth's surface, so that when he comes out of the clouds he may be able to know exactly where he is. The lecturer has pointed out that in ordinary good weather it is very easy to find the way with the ordinary maps, but that unfortunately airmen do not always fly in normal conditions, especially here in Europe where there is a good deal of cloud. So what seems to be required are maps which will have none of the unnecessary detail, but will have the conspicuous features perhaps exaggerated, and with some form of conventional sign by which the airman should be able to find his way and identify where he is. You will, I know, wish to give Captain Alan Lloyd a very hearty vote of thanks for his lecture, which we consider of great value to us.

\section{THE EVOLUTION OF THE HASTINGS COASTLINE}

\section{Miss E. M. Ward, M.A., B.Sc.}

\section{Read at the Afternoon Meeting of the Society, 8 March 1920.}

RETWEEN Beachy Head and the North Foreland the eroded 1 Wealden dome is cut short by the Channel. Three hill ridgesthe South Downs, the Forest Ridge and the North Downs-end abruptly upon the coast in high cliffs. North of them the low upfold of Thanet is bordered by equally steep but necessarily lower sea cliffs. Between these belts of higher land lie the Wealds of Sussex and of Kent and the flat lands of the lower Stour which separate Thanet from the North Downs. Bounding upland and lowland alike this transverse Wealden coast follows to-day an even line with broad and gentle curves except where Dungeness projects sharply into deep water.

In later Neolithic times the Channel waters washed along a type of coastline very different from that of modern days. The tides ebbed and flowed over Pevensey levels and Romney Marsh, and swung to and fro in the Wantsum strait that lay between a greater Thanet and the mainland. Sheltering the shallow bays that stretched away into the woodlands of the vales of Sussex and Kent the hill ridges ran far out into the Straits. Sea 
and land lay interlocked in bays and headlands when Neolithic man dwelt upon the open Downland.

Headland and bay, the one blunted, the other silted up, are gone from the coast. Along the cliffed hill ridges coastlines similarly but more minutely irregular have been submitted to the same changes. The little estuaries and bays and headlands that once diversified the sea margin of the Downs and the Forest Ridge are to-day smoothed out like the greater irregularities of the coastline of which they form a part.

The cliffs of the Forest Ridge extend some 5 or 6 miles along the shore, and in this length are reproduced in miniature the topographical features characteristic of the whole transverse Wealden coast. A detailed

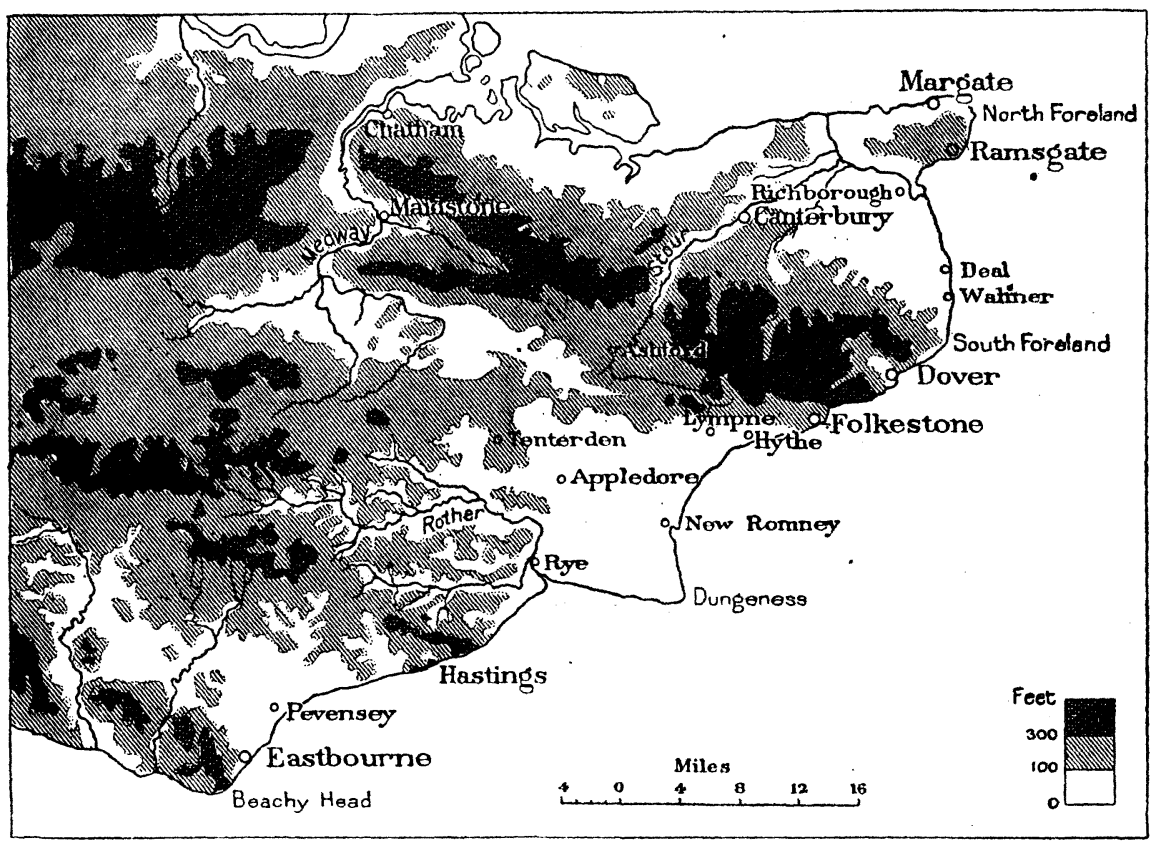

Sketch-map of the Downs and the Forest Ridge, S.E. England

consideration of the course of coastal development here should serve to make clear also that of the main coastline.

Where it meets the sea the Forest Ridge is furrowed by a succession of little valleys. The town of St. Leonards is spread over a series of gentle uplands and hollows, that slope to-day to the inexorable line of the parades. To the east modern Hastings lies athwart the sharply defined Priory Valley that debouches between the Castle Hill and the high ground of St. Leonards. Eastward again the old fisher town is narrowly constricted between the green slopes of the Castle Hill and the East Hill, where the Bourne Valley slopes to the sea. Beyond the old town and the valley of the now vanished Bourne rise the East Hill and the fine uplands that, intersected by Ecclesbourne and Fairlight Glens, and the little valley 


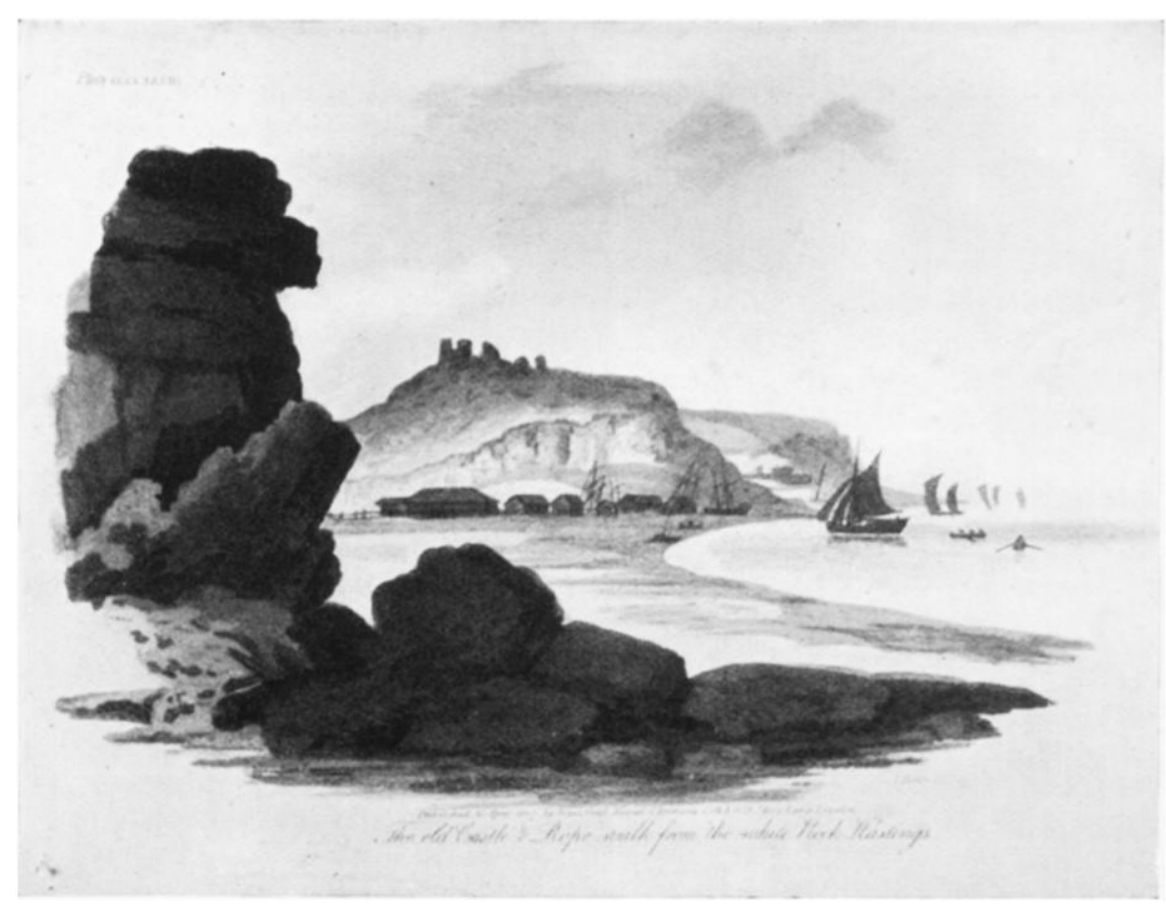

HASTINGS FROM THE WHITE ROCK, c. 18I7.

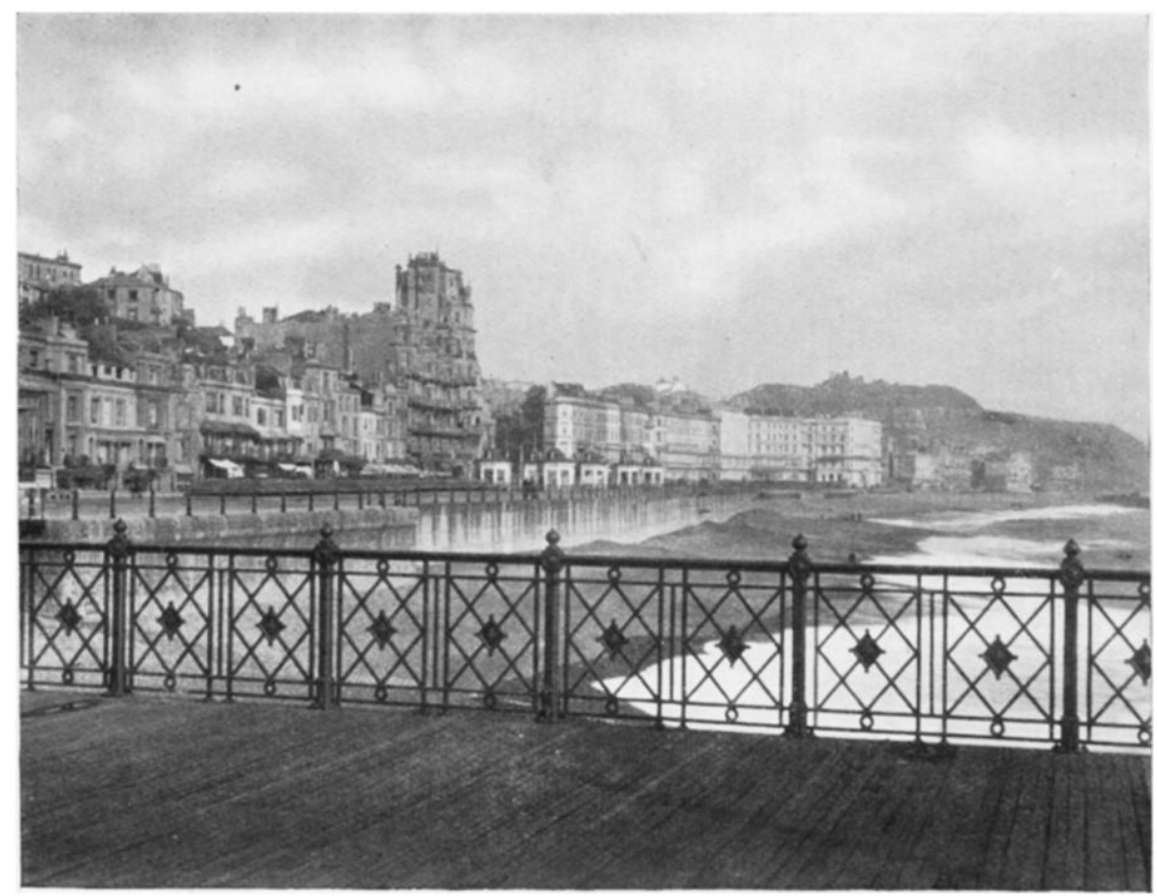

HASTINGS FROM THE WHITE ROCK: PRESENT DAY

This content downloaded from 134.117.10.200 on Mon, 27 Jun 2016 17:34:15 UTC All use subject to http://about.jstor.org/terms 


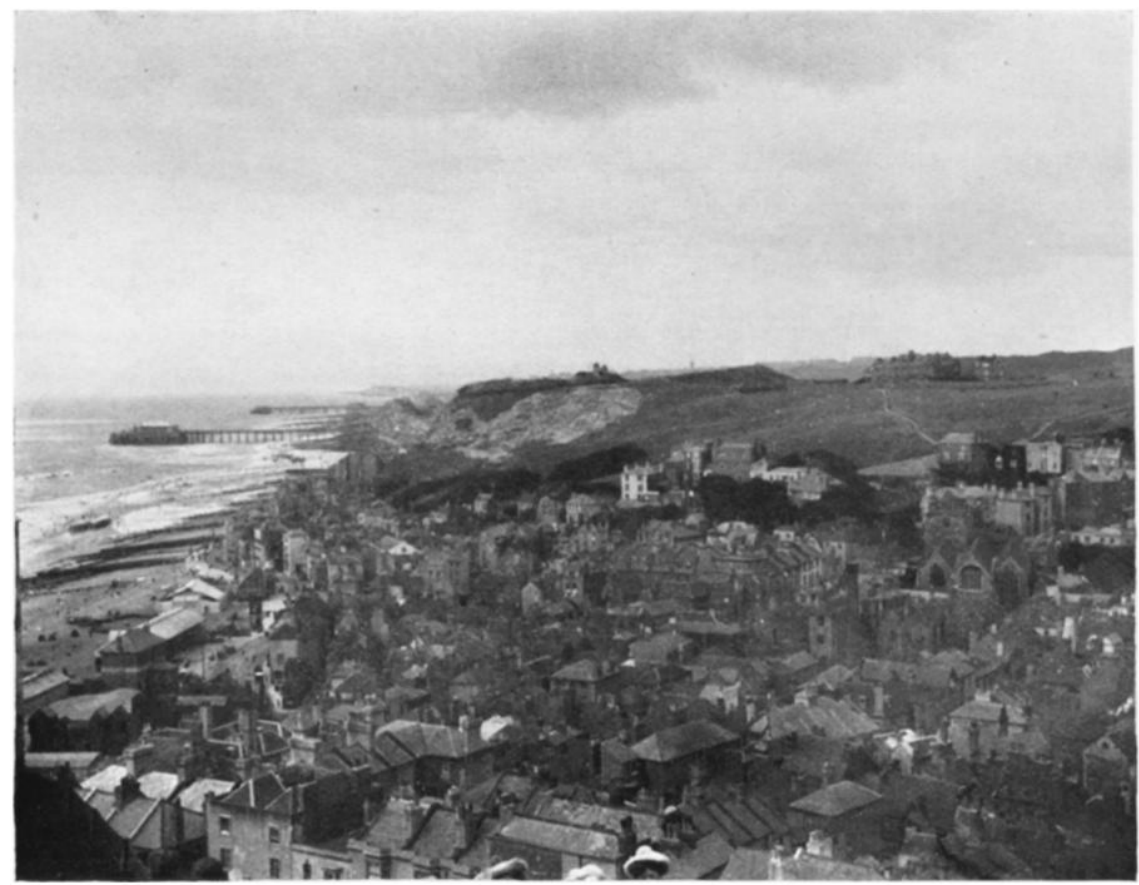

HASTINGS FROM THE EAST HILL, LOOKING WEST

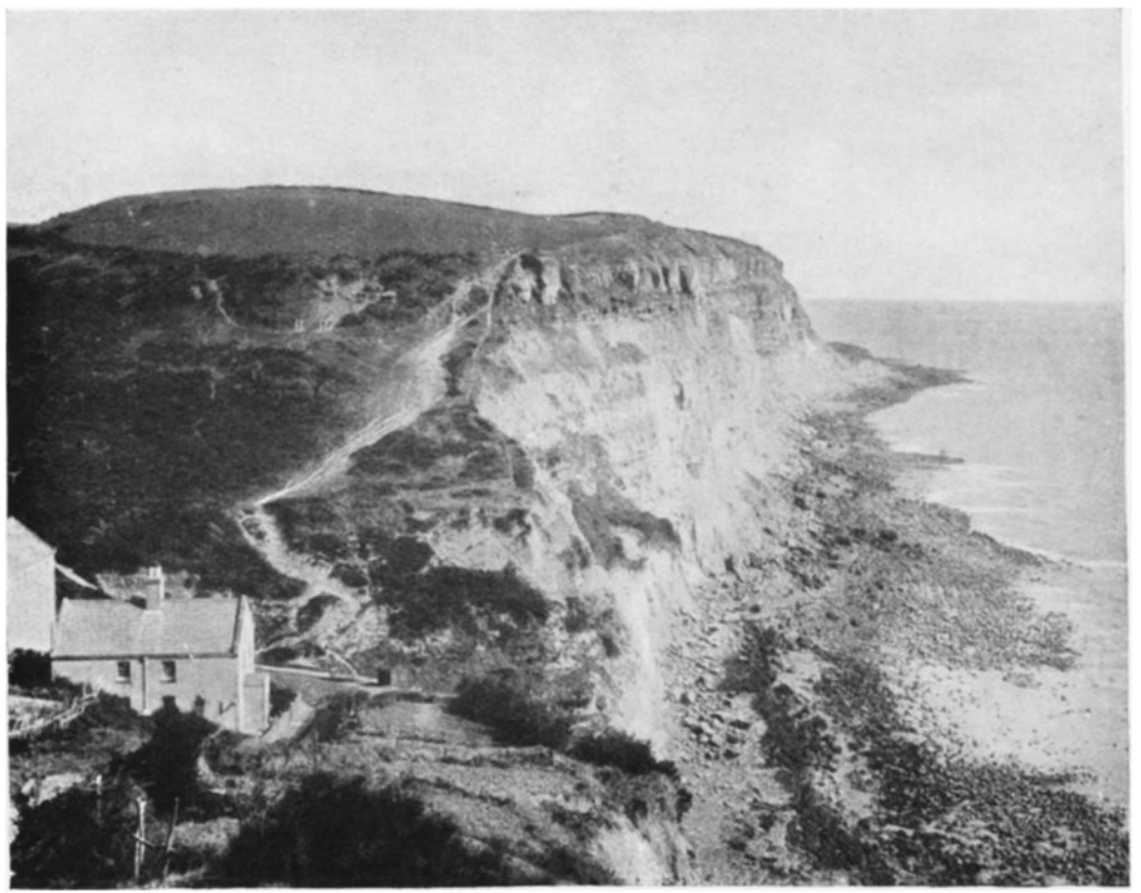

ECCLESBOURNE GLEN, EAST OF HASTINGS 
east of the latter, stretch to the dead levels of Romney Marsh. From the standpoint of coastal evolution the salient characteristics of this length of coastline between Bexhill and Romney Marsh are the cliffed condition of the coastal uplands; the existence in the Priory Valley of a flat alluvial tract now occupied in part by the Alexandra Park, and which follows the curve of the valley for some $\mathrm{I} \frac{1}{2}$ miles inland; the straightness of the existing coast ; and finally the presence throughout its length of a sand or shingle beach. The cliffs, where they are not masked as at St. Leonards and in western Hastings by buildings, rise in nearly vertical walls, increasing in altitude from the low clay cliffs at Bexhill, to some 200 feet at the Castle and over 300 feet near Fairlight. Cliffs prove coastal recession, and these various headlands must once have projected further seawards. The alluvial tract of land in the Priory Valley, still below highwater level, was once an arm of the sea. The little river Asten which now flows out by a sluice through the shingle banks at the western end of St. Leonards was similarly estuarine. The even coastline of to-day is then a geologically recent development, and has evolved from the originally irregular shoreline of projecting headlands and tidal valley mouths.

At the close of the coastal subsidence which took place in Neolithic times, the uplands of the Forest Ridge undoubtedly extended further seawards, but since the depression allowed the sea to flow up the valley of the Priory Brook - a feeble stream of origin geologically recent and thence unlikely to possess a long and level lower reach-for a distance of $\mathbf{1} \frac{1}{2}$ miles from the existing coast, it would seem that the headlands on either side can at this time scarcely have projected more than I or 2 miles beyond their present position. The vale of the even smaller Bourne debouches at sea-level, so apparently does Fairlight Glen, though here the stream emerges to the beach through landslip debris. At Ecclesbourne Glen the waves, working more rapidly than the tiny rivulet could deepen its bed, have cut back the mouth of the valley so that the stream falls over a little cliff perhaps 30 feet on to the shore; but this may not imply any great recession, since here again it seems highly improbable that this streamlet should have had any but a relatively steep course.

The rate of recession of the Fairlight Cliffs at a few points of most rapid retreat has for the past thirty years averaged at least 3 feet annually (P. H. Palmer, M.Inst.c.E., Borough Engineer). This may have been less in the immediately preceding past, as before the Hastings groynes held up the longshore drift from the west, a shingle beach must have helped to protect this part of the coast. Writing in $185 \mathrm{I}$, Redman (Min. Proc. Inst. C.E., vol. II, "On the Alluvial Formations and Local Changes of the South Coast of England") states that shingle extended at that time, except across the harbour mouths, from Langley Point near Eastbourne to Dungeness. Supposing the present maximum rate of recession to have been the rate for the whole headland since the close of the Neolithic depression, these cliffs would have receded 2 miles in the 3500 years that 
Reid ('Submerged Forests,' Camb. University Press) has estimated have elapsed since then. That they can have projected some 7 miles further out at the commencement of the period of unchanging sea-level, as Gulliver ("Dungeness Foreland," Geographical Journal, vol. 9) has suggested, seems at variance not only with the sea-level outfall of the local streams, but also with the observed rate of retreat of the cliffs. Estimates as to the extent of the early projection of these headlands may vary; as to the fact of their former extension seawards there is no doubt.

At the present day the lengths of cliff coast in this region are being actively cut back wherever they are not artificially protected. West of the monotonous lines of parades that extend from St. Leonards to the fisher town, the clay cliffs on either side of Bexhill are rapidly receding; the parades themselves-massive and fronted by great stone and timber groynes-are protected against the sea as elaborately as a fortress against an enemy, and yet suffer damage in great storms. Opposite the fisher town the breakwater of the latest (and seventh) unsuccessful attempt at harbour construction, built in 1893 , is already falling into ruin. Beyond the last sea wall east of Rock-a-Nore, the cliffs retreat ceaselessly before the waves. Landslips, concave to the sea, extend inland across cliff paths-the early coastguard station at Ecclesbourne has been washed away, and the new (and now deserted) coastguard cottages are already in danger. The steps down to the shore from this glen have recently been destroyed, and a vertical cliff now makes communication between the glen and the shore impossible.

The conditions at the close of the period of changing sea-level can only be deduced from existing geological and topographical features. Not until the days of the Saxons is it possible to gain from human records some idea of the character of the coastline. By now the town of Hastings had come into existence. It appears to have stood-though the town itself and most likely its actual site are long vanished-on low ground at the mouth, and probably on the western side of a river-like estuary that still, as in Neolithic days, stretched inland between the slopes of Priory Valley. Above the estuary on the east the Castle Hill extended both further seawards and more to the west than it does now. On the opposite side of the haven, and immediately west of the prosperous town, the land rose again and pro. jected out to sea in the bold and rocky headland, now vanished, of White Rock. This high ground forms to-day the area between Hastings railway station and Warrior Square. West of White Rock the coast must have consisted of low cliffs and small bays where the gentle undulations now covered by the grey streets and houses of St. Leonards ended on the shore, and somewhere along here or further westward must have lain the wandering outlet of the Asten estuary. The little Bourne Valley, to-day only some 2 miles long, was evidently not occupied like its western neighbour by the sea-since the town that a little later grew up here appears to have had no haven of its own and to have been dependent on that of the Priory Valley. 
Again judging from the present rate of coast recession, the cliffs of Fairlight and those to the west may have stood at this time perhaps half a mile seaward of their present position, and small estuaries may still have survived at the mouths of the various little glens.

Before briefly considering the known course of development of the Hastings coasts since the time of the Saxon town, it may be well to review,. very shortly, the local movements of the inshore waters which have brought about that development. Sub-aerial weathering may be neglected as common to coasts and countryside alike, its increased efficiency along the land margin being dependent on the work of marine forces.

Here at Hastings the coast is exposed to the attack of very heavy stormwaves. The largest and most destructive waves are caused by south-west winds. Winds from south or west blow for nearly half the days in every year, and of the total number of gales annually over one-third are from the south-west. The tidal range reaches a local maximum on this part of the coast, and at spring tides the line of breaking waves rises and falls through a vertical height of 24 feet. Moreover, the size of the Atlantic waves driven from the west and the shallowness of the Straits must ensure a slow degradation of the sea bottom even beyond the inshore zone of more active wave-action. Thus conditions exist not only for effective attack on the land margin, but also for the maintenance of that attack.

The tidal wave, here as elsewhere in our shallow waters, is one of translation. The tidal streams that pour ceaselessly to and fro through Dover Straits seldom exceed, offshore, a speed of 3 knots per hour on the surface, and 2 knots on the bottom. Their direct effect on erosion is probably negligible. But currents of even such comparatively low velocities can transport sand, and move pebbles of about I inch in diameter. Very generally the eastward tidal stream flows more rapidly and lasts a shorter time than that towards the west; hence a dominant drift of coarser débris towards the east might be expected. Off Hastings, the east-going stream runs from about three and a half hours before the time of local high water until about two and a half hours after it-thus, when these times hold immediately inshore, that portion of the beach above, approximately, halftide level is exposed only to an east-going tidal stream.

The predominant westerly winds, the fact that the largest waves come from the west, and the prevalence of the eastward tidal stream for some hours before and after high water all result in a general drift of beach material alongshore from the south-west towards the north-east. Waves erode the shoreline; obliquely impinging waves, wind-generated currents and tidal streams urge the products of erosion north-eastwards. Wave attack and the famous "eastward drift" have been and remain the two great factors in the development of this coastline. From their continued operation there would normally result a general recession of the coast, accompanied by the relatively rapid retreat of any projecting headlands and the formation of barrier beaches across the mouths of inlets. The 


\section{II2 THE EVOLUTION OF THE HASTINGS COASTLINE}

silting of the enclosed inlets and blunting of the headlands would create a smooth coastline fringed by eastward-travelling beaches and of gently curving outline so adjusted to wave attack that lowlying and upland shores give way at equal rates before the sea.

We may now briefly trace the development of the coastline as it has been recorded in historical times and see how far that development accords with what theoretical considerations would lead one to anticipate. The coast of the Bourne Valley has suffered relatively little modification. The town at its mouth was founded in the eleventh century, and appears, as already stated, to have had no estuarine haven. Both headlands at the outlet of the Bourne have been greatly eroded by the sea. The Castle Hill may be more conveniently considered later. The East Hill is now

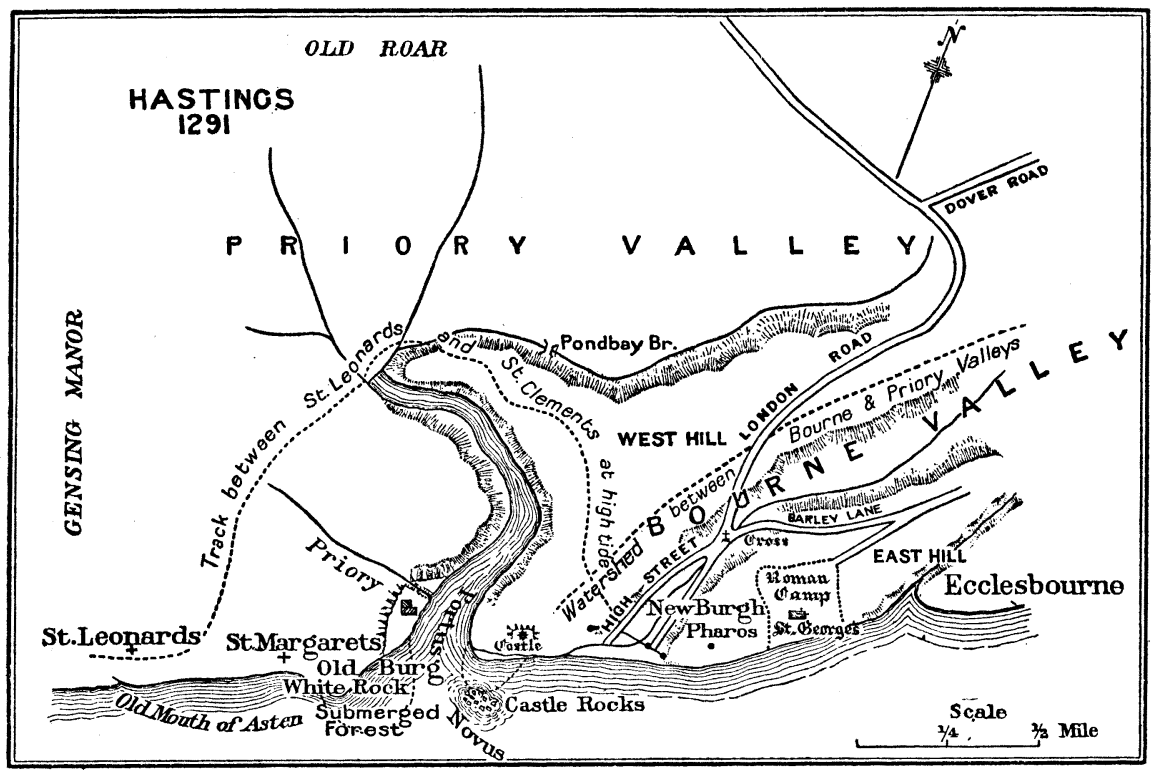

protected by a sea wall and groynes; shingle has accumulated below it, and various buildings stand at the foot of the sheer cliffs that comparatively recently were washed by the waves. The low land at the mouth of the valley is reputed to have suffered some early loss, but the town itself, whose walls extended almost to the beach, was not apparently encroached upon, and to-day a wide bank of shingle, bearing huts for fishing-nets, and capstans, extends in front of the town, which itself has expanded seawards from the line of its old sea wall.

The Priory Valley has had a more eventful history. The Saxon town of Hastings, on the western side of the entrance to the Priory estuary, had by the eleventh century declined from the great importance to which it had attained in the reign of Edward the Confessor; a decline attributed in part to the ravages of the sea. It appears from a record of the bursting 
of embankments in 1325 that it was dependent on the protection of sea walls, and was thus built on low ground. Probably, therefore, sufficient shingle had already drifted round White Rock to allow of the silting and reclamation behind it of an area to windward of the estuary. Reclamations on the western sides of river mouths are very common on the south coast, and such areas, unless well defended, are liable to periodic inundation by the sea. By the end of this century the site had become uninhabitable-the citizens had migrated to the new town already established in the Bourne Valley, or to a settlement that grew up, for reasons which will appear later, round the Castle Hill, The Priory building itself stood near the present Hastings railway station, and by I 412 its inhabitants had to abandon this site, which was "laid waste by the sea," and migrate to Warbleton. Thus by this date a lowlying region at the mouth of the valley, an area formerly inhabited, and extending at least as far inland as the railway station of to-day, was either washed away or reduced to a swampy condition.

This advance of the sea upon the low coast of the valley mouth was the necessary accompaniment of the erosion of the headlands that formerly protected it on either side.

By I $44^{\circ}$ the parishes of St. Leonards and St. Margarets, which extended west of the White Rock headland, as well as those parishes at the mouth of the Priory, Valley, were noted as having suffered great losses by the sea. The Castle Hill was also being actively cut back at this time. In 1236 the original Church of St. Clements, which stood on the edge of the hill, was lost, and by $\mathrm{I} 33^{\mathrm{I}}$ it is stated that a large part of the Castle was already fallen into the sea.

The Saxon Hastings vanished; its estuarine haven in due time disappeared also. The eastward drift of sand and shingle alongshore, becoming more powerful for reasons which will be discussed later, was by now having a marked effect. By 1380 it is recorded that the outlet of the Priory Brook, and hence the mouth of the haven, was deflected to the utmost limits of its valley, so that the brook flowed out round the foot of the eastern headland below the Castle cliffs. This deflection was caused by a bank of shingle that had drifted from the west round the receding headland of White Rock, and had gradually forced the stream to leeward-a bank that must have lain considerably inland of the present line of beach. A fresh settlement, as above noted, grew up at this new entrance to the haven, founded by migrants from the Saxon town whose site must have become inundated in spite of the growing shingle bank. From this date the Priory Valley itself remained uninhabited-save for some few scattered houses on the hill slopes - until modern Hastings, about the middle of the seventeenth century, began to spread slowly westward from what was by then the Old Town of the Bourne Valley, so slowly that a century later the town still lay mainly east of the Castle Hill. For nearly four centuries, therefore, the mother valley lay silent and depopulated. The 
haven, which some records appear to suggest may have become nearly useless for navigation as early as the twelfth century, became finally silted up during the passage of this length of time. One of its entrances seems, from a discovery of an old sluice gate, to have been situated some 300 yards south of Hastings station, or about 200 yards inland from the modern line of the parades. In the sixteenth century attempts had been unsuccessfully made to repair the haven, and at this period a considerable tidal inlet still existed. In 1635 a final scheme for reopening the old harbour came to nought, but a map of 1746 still shows a haven marked in the neighbourhood, and rather south of the present Hastings station. Though its usefulness as a harbourage diminished and finally disappeared, the area occupied by the old estuary long remained an amphibious region, useful neither as land nor water. About the end of the eighteenth century high tide still extended a mile or so up the valley, the site of the present

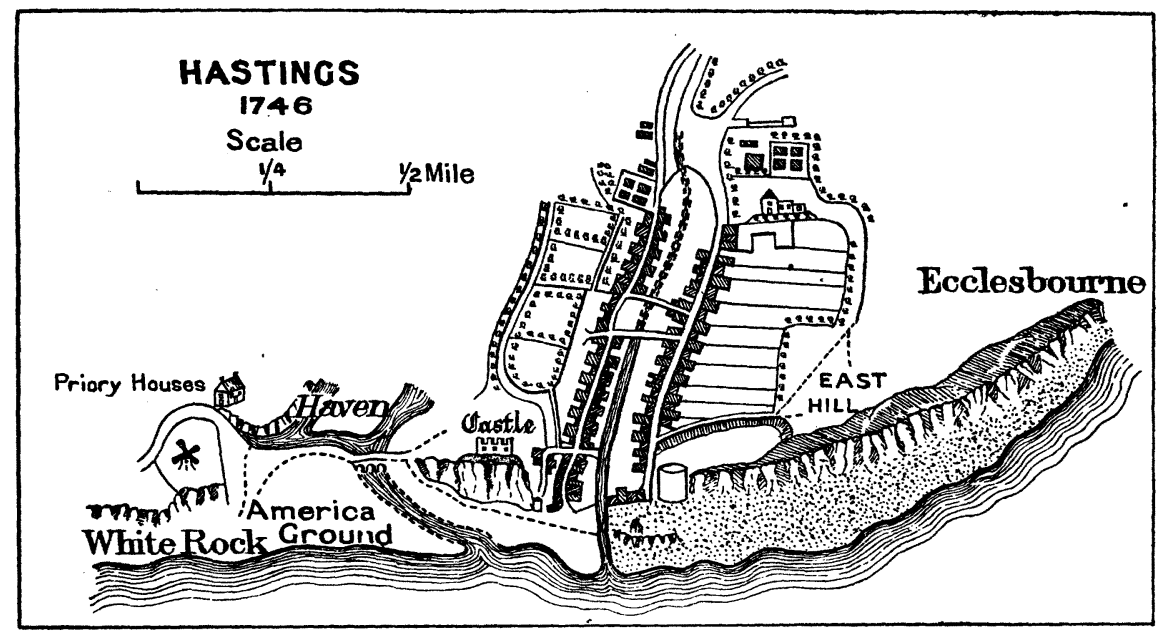

railway station was occupied by a "boggy reed bed," and that of the Cricket Ground by a pond. Two lagoons lay behind the shingle banks, one on either side of the Priory Brook. By 1823 these lagoons had vanished and the eastern one was built over (A. Ballard, 'The Sussex Coastline,' Sussex Arch. Coll., vol. 53).

The silting and reclamation of this estuarine tract took place behind a widening belt of shingle. The map of 1746 shows the Priory haven, separated from the sea by an area of land then known as the America Ground, which extended eastwards from the headland of White Rock. Across the eastern end of this area the Priory Brook communicated with the sea, spanned where it left the haven by the Priory Bridge. On the site of the Priory Bridge stands to-day the Albert Memorial. The tract of land enclosing the haven lay between the present Cambridge Road and the sea, and consisted, as it does still, of shingle. In $x 746$ it was still an uninhabited and waste area, but by the early nineteenth century it was 
partly built over, and in $185^{\circ}$ the present streets and parades were first laid out. It was behind the widening shingle banks of the America Ground that the old estuary, now become a marsh, was gradually reclaimed. The area round the present railway station was drained in the middle nineteenth century, and certain roads were raised above sea-level with material from the railway tunnels. Now the former haven and the shingle area of the America Ground are alike indistinguishable from the rest of the town, though in storms the sea still flows up the old course of the Priory Brook-which to-day runs under the streets and flows out through a culvert-surrounds the Albert Memorial and penetrates as far as the Cricket Ground, some 300 yards inland.

The erosion and recession of the headland cliffs that was already

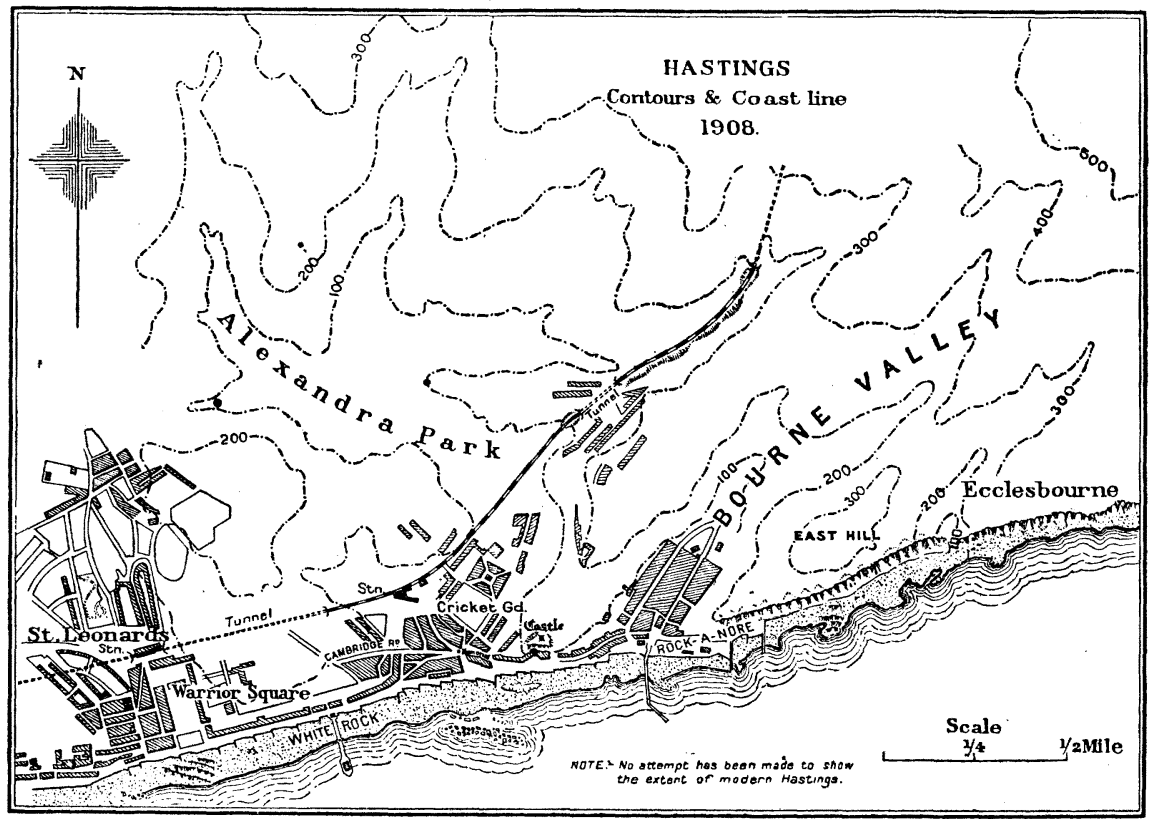

marked in the earlier stages of the silting haven continued throughout its further decline. Plentiful proof exists of the continued erosion of the St. Leonards coast and the White Rock headland. From old prints and maps and local tradition, it appears that a rough road at one time ran on the beach below this craggy headland towards Bexhill, but by 1833 this road; that must always have been liable to periodic inundation, was gone and the headland itself much broken up by storms. The following year the townsfolk, being possessed no doubt of orderly minds, had the picturesque rocky point removed and the cliffs cut back to make room for the present singularly uninspiring White Rock Parade. The site of the old headland is marked by the present curve in the edge of the parade at the east end of the Baths, and until groynes were erected the waves 
continued to attack the sea wall here, which was frequently damaged, as energetically as they had assailed the beautiful headland. The groynes had accumulated by 1878 so much shingle that the promenade at this point was widened and the Baths built seawards of the original sea wall. During the nineteenth century the main coast road through St. Leonards west of White Rock was diverted inland, and Martello towers built in I805 were washed away.

Up till the fourteenth century the cliffs beneath the Castle were freely attacked by the waves, but towards the latter part of this century, as has been seen above, the deflected Priory Brook and the shingle bank that constrained its course stretched round the base of the Castle Hill, though the breadth of shingle that from this time gradually accumulated between the cliffs and the sea was not built upon until about the same period as was the America Ground. George Street grew up in the middle of the seventeenth century along the more sheltered eastern base of the Castle headland, but the strip of shingle below the face of the cliffs directly fronting the sea was not built upon until later. By 1800 only a few houses stood along it, the inhabited area extending westward as time went on. Here, as on the opposite headland, the cliff face, broken up by wave erosion and weathering, was cut back to make room for terraces of houses, and now the shingle tract below the Castle cliffs is entirely built over and protected by the inevitable sea wall and groynes.

The building, in 1812, of the Marine Parade below the more easterly part of the Castle cliffs was the beginning of the modern series of sea walls and promenades. By the middle of this century the whole length of shore from St. Leonards to the old fisher town was protected. Before the nineteenth century attempts at harbour construction and coast defence were limited to local and isolated schemes, soon demolished by the sea. Probably only for the last hundred years or so has the course of coastal development here been effectively modified by human interference.

A consideration of the development of this short length of coastline brings certain salient points of coastal evolution into prominence. It is known that the last considerable change of sea-level here took place in Neolithic times, and resulted in the deeper submergence of the land. From historical evidence it is clear that the time which elapsed between the close of the period of depression and the growth of the first town in the Saxon period sufficed only for the commencement of the sea's work upon the irregular coastline. In the tenth century A.D. conditions still approximated more nearly to those of Neolithic days than to those of our own times-the headlands were no doubt cut back considerably, but the results of such recession on the valley outlets can only have been beginning to appear. The irregularity of outline characteristic of the early stage of its development influenced the attack of the waves upon the coast of the Forest Ridge. Wave erosion was concentrated upon the headlands, and facilitated by the deposition in the little bays and inlets of the shore waste 
which would on a smooth coastline have early begun to encumber the base of the cliffs. The projection of headlands into comparatively deep water interfered with the 'longshore drift of beach material, which drift, in so far as it existed, was confined to short lengths of coastline, each cut off from the 'longshore currents and shifting sand and shingle of its neighbour.

The continued recession of the headlands aided the regularization of the coastal outline in other ways besides that of the blunting of its more prominent projections. Their erosion supplied sand and shingle, and, since the land as a whole rose towards the interior, supplied it in increasing quantities. Their retreat permitted in time the amalgamation of two or more of the previously independent systems of 'longshore drift currents, so that increasing lengths of coastline came under the influence of one dominant drift, here that to the eastward, and were bordered by beach material drawn in part from increasingly distant sources. White Rock headland probably acted as a more or less perfect " drift divide" under whose shelter the tide ebbed and flowed comparatively unhindered in the Priory estuary. By the fourteenth century however, as we have seen, the valley mouth was barred across by shingle banks. Their position in line with the coast and across the estuary was determined mainly by the inertia of the 'longshore drift. Their extension from west to east athwart the estuary implied that a length of coastline to windward had been so far smoothed as to allow of a flow of shore waste eastward from considerable distances round the receding crags of White Rock. The growth of the shingle spit across the tidal fairway of the estuary, opposed increasingly by the flood and ebb currents through the narrowing opening, only became possible when beach materials travelled along the spit, to be deposited at its head, in greater quantities than could be removed by the scour of the tides or supplied by a restricted length of shoreline. By this time shingle from distant sources may have contributed to the Priory spit, since it is probable that the banks across the mouth of Pevensey Bay by now permitted the 'longshore drift of shingle formerly here obstructed. Eventually the Priory spit forced the narrowed outlet of the estuary right against the Castle Hill, and apparently a more or less stable condition ensued, shingle from the west crossing without as a rule permanently obstructing the outflow channel and continuing round the base of the Castle cliffs towards the east. Normally a channel such as this would be entirely choked at intervals; be accompanied by one or more similar tidal gaps at other times ; and be subject to constant changes of position, any established channel moving always with the 'longsho re drift towards the east. Records of such changes at Hastings are however not known to the author. Behind the shingle banks the estuary soon became silted. It was small and shallow, and could at any time have had only a small volume of tidal waters entering and leaving it. Now it was cut off from the tides, and twice daily its seaward flow was stilled when high water 
lapped against the outer shingle banks. Into its always quiet waters the little hill streams brought their burden of silt. Thus it became steadily shallower, marsh vegetation grew up, and at last man intervened and by finally barring out even the greater storm waves and draining the swampy valley floor created a land area fated by his action to remain at the level, rather below that of high-water mark, to which it had risen when he put a stop to further deposition.

The period occupied by the silting of Priory Valley was on the open coastline one of cliff recession. The growth of beaches in coastal embayments probably commences with the first wave attacks on the coastline, but cliff beaches are a later development and only become relatively permanent when the waves have cut at the cliff foot a coastal shelf of such a width and slope as to allow of the deposition and retention of beach upon it. Thus on this coastline in the fourteenth century the sea still washed the base of the Castle cliffs when the Priory Haven was already barred by shingle. Before any continuous system of sea walls or groynes was created at Hastings the cliffs were everywhere so far receded as to be fringed by shingle beaches, narrow however compared with those opposite the Priory and Bourne valleys.

The latter vales had by the middle of last century developed wide areas of shingle before their mouths. The America Ground, as we have seen, had grown seawards from the original shingle spit that had barred the Priory Haven. This widening of the shingle deposits was due either to the accumulation of beach travelling from the west and checked from at once continuing further by the tidal Priory Brook, or to an outward swinging of the line of 'longshore drift owing to changes in the coast to windward, which must have given it its direction. The wide beach in front of the Old Town may similarly be due to the 'longshore drift currents which, increasing in inertia as they gained in volume with the regularization of the coastline, may have ceased to follow the actual coast of the slight embayment and extended in a more direct line from Castle Hill to Rocka-Nore. In any case such widening shingle deposits grow outwards until the amount washed away from their more exposed and probably longer coastlines equals that brought by the 'longshore currents. Such a state of stability would appear to have been attained at Hastings. It must be remembered, however, that the present system of groynes, which prevent any 'longshore drift of shingle beyond Hastings to the east, has in modern times materially increased the width of shingle beaches in front of the town.

Prior to the present groyning the whole coast of the Forest Ridge was, as has been stated above, fringed by beach. Moreover, the alternations of ridge and vale had ceased to be marked by any corresponding irregularity in the coastal outline, except for the almost silted Priory estuary, before human constructions effectively interfered with natural processes along the coast. Here, then, an irregular coastline of submergence with headlands 
projecting beachless far out into the channel and narrow estuaries winding up the miniature valleys, has been reduced since the Neolithic period to the present even shoreline cutting straight across the ends of ridges and valleys, and everywhere fringed by a continuous line of beach deposits.

A similar development of the coastline between Beachy Head and the North Foreland has taken place during the same lapse of time. Towards the close of the Roman period in Britain the eastern portion of Romney Marsh had been reclaimed, but the sea still penetrated far inland over the western portion. Anderida, which later became Pevensey, was a tidal harbour. Richborough and Reculver stood at either end of the still navigable Wantsum. Dover, like Hastings, was originally on a small estuary. At Dover the Dwr flows out at sea-level between chalk cliffs, and its mouth was probably yet estuarine though already greatly silted. By the Norman Conquest coastal development had advanced further, with most marked results on the bay areas. No fresh reclamations had taken place in the main area of Romney Marsh, but certain areas had been reclaimed at the base of Dungeness. This shingle foreland had begun to form at an unknown date from the banks extending across the wide estuarine bay. Pevensey harbour remained tidal though the shallow bay was silting rapidly. In the reign of King John, Pevensey applied for a licence to build a new town nearer the sea. Sandwich had grown up seawards of Richborough on the silting. Wantsum. All traces of an estuary at Dover were extinguished.

The main headlands since the Roman period have been altered rather in form than in position. The Roman ports of Ramsgate and Dover are still in existence. If Hastings were not a Roman settlement it has nevertheless been a port since early Saxon days. The headland cliffs have been cut back into an even line, but erosion has not proceeded so far as to remove much land at the mouths of the former inlets.

Silting of the three great areas of submerged lowlands has brought about more notable changes in the coastal outline. Space is lacking to detail here the various stages by which they became obliterated, but fairly full records exist of the advance of deposition and of reclamation which left one port after another stranded inland amidst green country. Romney Marsh and Pevensey Levels became gradually entirely silted behind their shingle banks. The northern arm of the Wantsum was early choked; the southern reach was first partly enclosed by a shingle bank which grew south from the Thanet shore and pushed the tidal channel south with it. On either side of this constricted channel there grew up Sandwich and the vanished town of Stonar. Later sand drifting from the south-west spread between Sandwich and the sea, and continued northwards until the only communication between that town and open water was by a tortuous channel flowing out under the Thanet cliffs.

Viewed broadly, it is clear that a similar development has taken place for this transverse coast as a whole, as in the case of the cliffs and inlets 
of the Forest Ridge. Headlands have been eroded, and embayments silted behind shingle banks. A regularized coastline such as this presents none of the variety of deposition forms which it possessed at one time, and which still exists in regions where each inlet or pronounced bend in the coastline gives rise to spits and bars, not yet obliterated by silting of the inlet or blunting of the projection. Here are found no such examples of growing, stable, and eroded shingle spits as occur, for example, on the south coast west of Beachy Head. The shingle foreland of Dungeness has, however, not yet reached a state of equilibrium. It is still extending its point seawards, while Langney Point has ceased to grow, and is now retreating before the attack of the waves.

A study of the evolution of a submerged and transverse coastline like that of the eastern Wealden area affords an excellent preparation for the consideration of coastlines whose topography does not admit of so symmetrical a course of development. Submitted nearly everywhere to a somewhat similar movement of depression at the same period as the Kent and Sussex coasts, the shores of England and Wales have responded in ways as various as their structure and topography to the moulding action of the waves. Certain resistent lengths remain relatively unchanged; some few regions have attained a stage apparently further advanced than that reached by the transverse Wealden coast. Generally the state of development is rather behind that of this region. Each type of coastline presents its own problems-problems which are the more easily solved since lengths in almost every stage of development are available for comparison. The author is at present engaged upon a book, now nearing completion, in which the subject of coastal evolution is considered as applied to the shores of England and Wales.

Before the paper the President said: I have now to introduce Miss Ward, who was a student of geography at the Liverpool University under Prof. Roxby, and a tutor in geography at Liverpool for three years. She has made a special study of coast erosion, and she is going to give us this evening a lecture on coast erosion near Hastings. She is, I think, very shortly bringing out a book upon this subject which will be of great value and interest to us.

\section{Miss Ward then read the paper printed above, and a discussion followed.}

Dr. J. S. OwENS: It is with great pleasure that I listened to Miss Ward's paper, as it is very unusual to meet a lady who takes such an interest in this subject and deals with it in such a capable manner. There were a few points on which I should like to touch. One is the projection seaward of the cliffs at the commencement of the present cycle of erosion. I gathered that Miss Ward based her calculations upon a period of about 3500 to 4000 years and a rate of erosion of about 3 feet per annum; this gives about 2 miles projection. I think it probable that the rate of erosion at the present day is very much slower than it was in the period immediately following the commencement of the present cycle. First of all, as Miss Ward has pointed out, the erosion of a headland is much more rapid when there is some place for the material to go to. When the bays were there and unfilled, all the material 